(c) American Dairy Science Association, 2004.

\title{
Short Communication: Effects of Feeding Level on Energy Concentration in Grass Silage-Based Diets Offered to Dairy Cattle
}

\author{
T. Yan, C. P. Ferris, R. E. Agnew, and F. J. Gordon \\ The Agricultural Research Institute of Northern Ireland, \\ Hillsborough, Co Down, Northern Ireland BT26 6DR, Northern Ireland
}

fined as ME intake divided by ME requirement for maintenance. Thus, dietary ME concentration is reduced by 0.018 proportionately with each unit increase in feeding level above maintenance (Agricultural and Food Research Council, 1993). However, in view of the increased yield potential and intake capacity of dairy cows during the last $25 \mathrm{yr}$, the appropriateness of this feeding level correction factor needs to be re-examined. For example, regression techniques on recent data from 317 dairy and beef cattle (Yan et al., 2002) indicated the feeding level correction for ME to be lower (0.016). In addition, Yan et al. (2002) have developed 2 multiple regression equations to predict dietary $\mathrm{ME}$ and digestible energy (DE) concentration for cattle at any production feeding level using dietary ME and DE concentrations determined at maintenance. The objectives of the present study were to examine the effects of feeding level (3.03 to 3.99) on DE and ME concentrations in diets offered to high genetic merit cows and to evaluate the feeding level correction factors and equations proposed by Van Es (1975) and Yan et al. (2002).

Twelve grass silages, differing in harvest date, DM concentration, and digestibility, were produced from perennial ryegrass based swards. Mean silage analysis data are presented in Table 1 . These silages were mixed with either high or medium protein concentrate supplements (silage DM proportion, 0.33 to 0.72 ) to produce 13 mixed diets. The high protein concentrate contained (kg/kg fresh weight) barley, 0.410; soybean meal (48\% CP), 0.413; rapeseed meal, 0.112; molasses, 0.030; and a mineral and vitamin supplement, 0.035 . The medium protein concentrate contained ( $\mathrm{kg} / \mathrm{kg}$ fresh weight) barley, 0.300; maize gluten meal, 0.218; molassed sugar beet pulp, 0.150; citrus pulp or soybean hull, 0.150; soybean meal ( $48 \% \mathrm{CP}), 0.167$; and a mineral and vitamin supplement, 0.015. Full details of each of the silages and mixed diets offered were reported by Ferris et al. (2003). The mixed diets were offered ad libitum to late lactation Holstein-Friesian cows ( 3 cows per diet) tied in individual stalls for $21 \mathrm{~d}$. Fecal and urinary energy outputs were measured during the final $6 \mathrm{~d}$. During the 6-d measurement periods, samples of each silage were taken daily, sealed in polythene bags, and stored at $-20^{\circ} \mathrm{C}$. These frozen samples were subse- 
Table 1. Silage composition and performance of lactating dairy cows offered mixed diets at production feeding levels.

\begin{tabular}{|c|c|c|c|c|}
\hline & Minimum & Maximum & Mean & SD \\
\hline \multicolumn{5}{|l|}{ Silage chemical analysis $(\mathrm{n}=12)$} \\
\hline $\mathrm{ACTDM},{ }^{1} \mathrm{~kg} / \mathrm{kg}$ & 0.198 & 0.337 & 0.259 & 0.0490 \\
\hline Ash, kg/kg DM & 0.073 & 0.113 & 0.091 & 0.0130 \\
\hline $\mathrm{CP}, \mathrm{kg} / \mathrm{kg} \mathrm{DM}$ & 0.120 & 0.203 & 0.162 & 0.0241 \\
\hline Acid detergent fiber, kg/kg DM & 0.264 & 0.366 & 0.311 & 0.0363 \\
\hline Neutral detergent fiber, $\mathrm{kg} / \mathrm{kg}$ DM & 0.425 & 0.586 & 0.515 & 0.0524 \\
\hline Gross energy, MJ/kg DM & 17.5 & 19.7 & 19.0 & 0.62 \\
\hline $\mathrm{pH}$ & 4.05 & 4.56 & 4.18 & 0.142 \\
\hline Ammonia N/Total N & 0.080 & 0.156 & 0.106 & 0.0226 \\
\hline \multicolumn{5}{|l|}{ Cow data $(\mathrm{n}=13)$} \\
\hline Milk yield, kg/d & 12.6 & 21.4 & 17.4 & 2.77 \\
\hline Live weight, $\mathrm{kg}$ & 541 & 745 & 628 & 53.6 \\
\hline Silage proportion, kg/kg DM & 0.33 & 0.72 & 0.57 & 0.157 \\
\hline $\mathrm{DMI}, \mathrm{kg} / \mathrm{d}$ & 14.49 & 19.58 & 16.96 & 1.351 \\
\hline DE concentration, MJ/kg DM & 12.97 & 14.94 & 14.04 & 0.604 \\
\hline Feeding level ${ }^{2}$ & 3.03 & 3.99 & 3.42 & 0.302 \\
\hline
\end{tabular}

${ }^{1} \mathrm{ACTDM}=$ Alcohol-corrected toluene DM.

${ }^{2}$ As determined by Agricultural and Food Research Council (1993).

quently thawed and offered at maintenance feeding level to mature sheep (four sheep per silage) confined in digestibility crates. Silages were offered for $21 \mathrm{~d}$, and fecal and urinary energy outputs were determined during the final $6 \mathrm{~d}$. Methane production with the mixed diets offered to dairy cows and the unsupplemented silage diets given to sheep was estimated according to Yan et al. (2000) and Blaxter and Clapperson (1965), respectively. Using silage DM proportions in the mixed diets offered to dairy cows, the silage energy utilization data obtained using sheep, and tabulated concentrate data (Ministry of Agriculture, Fisheries and Food, 1990), DE and ME concentrations were estimated for mixed diets with sheep at maintenance feeding level.

A sensitivity analysis was used to examine the impact of using tabulated concentrate data. This analysis focused on barley, a major ingredient in each of the concentrate supplements offered. The impact of either increasing or decreasing the tabulated DE or ME concentration of barley (Ministry of Agriculture, Fisheries, and Food, 1990) by proportionately 0.05 and then recalculating the data for the mixed diets with sheep was examined. Increasing or deceasing the tabulated values by 0.05 had only a small and non-significant effect on the $\mathrm{DE}$ or ME concentration in the mixed diets with sheep at maintenance. This justifies the use of tabulated $\mathrm{DE}$ or $\mathrm{ME}$ values.

In a review of 72 comparisons from 17 comparative studies published since 1951, Yan et al. (2002) examined the impact of using OM digestibility derived from sheep for cattle at maintenance. The linear relationships in OM digestibility between the 2 species indicated no significant differences with concentrates, mixed diets, and good quality forages. This result was similar to the conclusion of a review of early studies reported by Aerts et al. (1984) that at maintenance, sheep and cattle did not differ systematically in digesting good quality grassland products. The mixed diets used in the present study had an OM digestibility, measured in cattle, ranging from 0.69 to 0.75 (mean, 0.72; SD, 0.019). Therefore, at maintenance feeding level, $\mathrm{ME}$ or DE concentration of mixed diets estimated in the present study with sheep is unlikely to differ greatly from those that would be with cattle.

Results were determined using mean data for each $\operatorname{diet}(n=13)$. Performance data for the lactating dairy cows are presented in Table 1 . Feeding levels, calculated as ME intake divided by ME requirement for maintenance (Agricultural and Food Research Council, 1993), ranged from 3.03 to 3.99 , with a mean of 3.42 (SD, 0.302). Concentrations of ME (11.93 vs. $12.37 \mathrm{MJ} /$ $\mathrm{kg} \mathrm{DM} ; P<0.01)$ and DE (14.04 vs. $14.74 \mathrm{MJ} / \mathrm{kg} \mathrm{DM}$; $P<0.001)$ in mixed diets determined in cows at production feeding level were significantly lower than those estimated in sheep at maintenance. Reduction rates ((maintenance - production)/maintenance) at the mean feeding level of 3.42 were 0.036 and 0.048 , respectively. With each unit increase in feeding level above maintenance, ME and DE concentration in mixed diets decreased by, proportionately, 0.015 and 0.020 (reduction rate divided by feeding level above maintenance), respectively. Although the reduction (0.015) in dietary $\mathrm{ME}$ concentration is close to that $(0.016)$ reported by Yan et al. (2002) using linear regression techniques, this value is lower than that $(0.018)$ proposed by Van Es (1975) and currently adopted by the Agricultural and Food Research Council (1993). 
Table 2. The evaluation of feeding level correction factors and equations proposed by Van Es (1975) and Yan et al. (2002) using treatment mean data $(n=13)$ and mean square prediction error (MSPE) techniques.

\begin{tabular}{|c|c|c|c|c|c|c|c|c|}
\hline \multirow[b]{2}{*}{ References } & \multirow[b]{2}{*}{ Factors } & \multicolumn{3}{|c|}{ Energy $^{1}$} & \multirow[b]{2}{*}{ MSPE } & \multicolumn{3}{|c|}{ Proportion of MSPE } \\
\hline & & Predicted & Actual & Bias & & Bias & Line & Random \\
\hline \multicolumn{9}{|c|}{ ME concentration } \\
\hline Yan et al. (2002) & Eq. $[1]^{2}$ & 11.9 & \multirow[t]{3}{*}{11.9} & -0.04 & 0.10 & 0.02 & 0.03 & 0.95 \\
\hline & 0.016 & 11.9 & & -0.04 & 0.09 & 0.01 & 0.01 & 0.98 \\
\hline Van Es (1975) & 0.018 & 11.8 & & -0.09 & 0.10 & 0.09 & 0.01 & 0.90 \\
\hline \multicolumn{9}{|c|}{ DE concentration } \\
\hline Yan et al. (2002) & Eq. $[2]^{3}$ & 14.0 & \multirow[t]{2}{*}{14.0} & -0.04 & 0.09 & 0.02 & 0.07 & 0.91 \\
\hline & 0.025 & 13.9 & & -0.19 & 0.15 & 0.23 & 0.03 & 0.74 \\
\hline
\end{tabular}

${ }^{1} \mathrm{Measured}$ in $\mathrm{MJ} / \mathrm{kg} \mathrm{DM}$.
${ }^{2} \mathrm{ME}_{\text {prod }}=[1.068-0.019 *(\mathrm{FL}-1)] * \mathrm{ME}_{\text {maint }}-0.755$, where $\mathrm{ME}_{\text {prod }}=$ metabolizable energy $(\mathrm{ME})$ concentra-
tion at production feeding level, $\mathrm{FL}-1=$ feeding level above maintenance, and $\mathrm{ME}_{\text {maint }}=\mathrm{ME}$ concentration
using data obtained from sheep at maintenance.
${ }^{3} \mathrm{DE}_{\text {prod }}=[0.891+(-0.027+0.018 * \mathrm{~S} / \mathrm{T}) *(\mathrm{FL}-1)] * \mathrm{DE}_{\text {maint }}+1.355$, where $\mathrm{DE}_{\text {prod }}=$ digestible energy
DE) concentration at production feeding level, $\mathrm{S} / \mathrm{T}=$ silage $\mathrm{DM}$ as a proportion of total diet, FL- $1=$ feeding
evel above maintenance, and $\mathrm{DE} \mathrm{E}_{\text {maint }}=\mathrm{DE}$ concentration using data obtained from sheep at maintenance.

The present data set was also used to evaluate the feeding level correction factors of Van Es (1975) (ME, 0.018 ) and Yan et al. (2002) (ME, 0.016; DE, 0.025) and the prediction equations (Eq. [1] and [2]) developed by Yan et al. (2002). These equations were developed to calculate dietary ME or DE concentration for cattle at production feeding level ( $\mathrm{ME}_{\text {prod }}$ or $\left.\mathrm{DE}_{\text {prod }}\right)$ using data obtained from sheep at maintenance $\left(\mathrm{ME}_{\text {maint }}\right.$ and $\mathrm{DE}$ maint), feeding levels above maintenance (FL-1; Agricultural and Food Research Council, 1993), and silage DM as a proportion of total $\operatorname{diet}(\mathrm{S} / \mathrm{T})$ :

$$
\begin{gathered}
\mathrm{ME}_{\mathrm{prod}}=[1.068-0.019 *(\mathrm{FL}-1)] \\
* \mathrm{ME}_{\text {maint }}-0.755 ; \\
\mathrm{DE}_{\mathrm{prod}}=\left[\begin{array}{c}
{[0.891+(-0.027+0.018 * \mathrm{~S} / \mathrm{T}) *} \\
(\mathrm{FL}-1)] * \mathrm{DE}_{\text {maint }}+1.355 .
\end{array}\right.
\end{gathered}
$$

This evaluation (Table 2) was undertaken using mean square prediction error (MSPE) analysis (Rook et al., 1990). Equation [1] and the ME correction factor (0.016) of Yan et al. (2002) predicted dietary ME concentration at production feeding level with a smaller bias than the ME correction factor (0.018) of Van Es (1975) (0.04 and 0.04 vs. $0.09 \mathrm{MJ} / \mathrm{kg} \mathrm{DM})$. The latter had a greater bias error and a smaller error of random variation as a proportion of MSPE than the former 2 approaches. For dietary DE concentration at production feeding level, Eq. [2] produced a smaller bias (0.04 vs. $0.19 \mathrm{MJ} / \mathrm{kg} \mathrm{DM})$, a smaller MSPE, and a greater proportion of error from random variation than the correction factor of 0.025 proposed by Yan et al. (2002). This result may reflect the latter not taking into account the dietary forage proportion and the rate of depression of energy digestibility associated with increasing feeding level being reduced with increasing dietary forage proportion (Yan et al., 2002). In conclusion, Eq. [1] and [2] and the $\mathrm{ME}$ correction factor of 0.016 , reported by Yan et al. (2002), provide good predictions of DE and ME concentrations in mixed diets for cattle at production feeding level, using DE and ME data obtained from sheep at maintenance feeding level.

\section{REFERENCES}

Agricultural and Food Research Council. 1993. Energy and Protein Requirements of Ruminants. CAB International, Wallingford, Oxon, UK.

Aerts, J. V., J. L. De Boever, B. G. Cottyn, D. L. De Brabander, and F. X. Buysse. 1984. Comparative digestibility of feedstuffs by sheep and cows. Anim. Feed Sci. Technol. 12:47-56.

Blaxter, K., and J. L. Clapperton. 1965. Prediction of the amount of methane produced by ruminants. Br. J. Nutr. 19:511-522.

Ferris, C. P., F. J. Gordon, D. C. Patterson, C. S. Mayne, and M. A. McCoy. 2003. A short-term comparison of the performance of four grassland-based systems of milk production for autumn-calving dairy cows. Grass Forage Sci. 58:192-209.

Ministry of Agriculture, Fisheries and Food. 1990. UK Tables of Nutritive Value and Chemical Composition of Feedingstuffs. D. I. Givens and A. R. Moss, ed. Rowett Research Services Ltd., Aberdeen, UK.

Rook, A. J., M. S. Dhanoa, and M. Gill. 1990. Prediction of the voluntary intake of grass silages by beef cattle. 3. Precision of alternative prediction models. Anim. Prod. 50:455-466.

Van Es, A. J. H. 1975. Feed evaluation for dairy cows. Livest. Prod. Sci. 2:95-107.

Yan, T., R. E. Agnew, and F. G. Gordon. 2002. The combined effects of animal species (sheep versus cattle) and level of feeding on digestible and metabolisable energy concentrations in grassbased diets of cattle. Anim. Sci. 75:141-151.

Yan, T., R. E. Agnew, F. J. Gordon, and M. G. Porter. 2000. The prediction of methane energy output in dairy and beef cattle offered grass silage-based diets. Livest. Prod. Sci. 64:253-263. 